\title{
Potensi Ekstrak Lengkuas sebagai Fungisida Nabati untuk Mengendalikan Penyakit Karat Daun Anggur (Phakopsora euvitis)
}

\section{Potency of Galangal Extract as Botanical Fungicide to Control Grape Leave Rust Disease (Phakopsora euvitis)}

\author{
Reza Fredo Simarmata, Christanti Sumardiyono, Ani Widiastuti* \\ Fakultas Pertanian Universitas Gadjah Mada, Jalan. Flora No. 1 Bulaksumur, \\ Yogyakarta, Indonesia, 55281
}

\begin{abstract}
ABSTRAK
Penyakit karat daun anggur yang disebabkan oleh Phakopsora euvitis merupakan salah satu penyakit penting tanaman anggur. Pengendalian dengan pestisida nabati untuk penyakit ini penting dikembangkan karena pemanfaatannya dapat menekan penggunaan pestisida kimia sintetik yang selama ini diaplikasikan. Penelitian ini bertujuan untuk mengetahui potensi ekstrak lengkuas sebagai fungisida nabati terhadap perkembangan $P$. euvitis, dan dibandingkan dengan fungisida mankozeb. Metode meliputi persiapan ekstrak lengkuas dalam metanol yang diuapkan, uji daya racun ekstrak lengkuas dan pestisida secara in vitro, penentuan $\mathrm{LC}_{50}$, dan pengujian in planta menggunakan bibit anggur di dalam pot plastik. Penentuan $\mathrm{LC}_{50}$ dilakukan dengan program SAS JMP Statistical Discovery. Uji in planta dilakukan dengan cara penyemprotan suspensi spora (urediniospora) dengan kerapatan $1 \times 10^{6} \mathrm{spora} \mathrm{mL}^{-1}$ dan penyemprotan ekstrak lengkuas atau mankozeb tiga hari setelah inokulasi pada konsentrasi $\mathrm{LC}_{90}$. Hasil penelitian menunjukkan perlakuan ekstrak lengkuas dapat menghambat perkecambahan spora $P$. euvitis. $\mathrm{LC}_{50}$ ekstrak lengkuas diperoleh sebesar 18.33 ppm dan $\mathrm{LC}_{90}$ sebesar $53.72 \mathrm{ppm}$; sementara $\mathrm{LC}_{50}$ mankozeb sebesar $65.52 \mathrm{ppm}$ dan $\mathrm{LC}_{90}$ sebesar $190.71 \mathrm{ppm}$. Pada uji in planta, penggunaan ekstrak lengkuas dengan konsentrasi $53.72 \mathrm{ppm}\left(\mathrm{LC}_{90}\right)$ dapat menurunkan intensitas penyakit karat daun pada anggur sebesar $16 \%$ pada hari ke-18, sementara fungisida mankozeb dengan konsentrasi $190.71 \mathrm{ppm}$ $\left(\mathrm{LC}_{90}\right)$ menurunkan intensitas penyakit sebesar $26.4 \%$ dibandingkan dengan kontrol positif atau tanaman sakit tanpa perlakuan. Ekstrak lengkuas memiliki potensi untuk dikembangkan sebagai pestisida nabati terhadap penyakit karat daun anggur.
\end{abstract}

Kata kunci: pengendalian penyakit, $\mathrm{LC}_{50}$, mankozeb

\begin{abstract}
Grape leaf rust caused by Phakopsora eutivitis is an important disease on grape plants. Botanical pesticide is important to be developed as its application may reduce the usage of synthetic chemical pesticides. This study aimed to determine potency of galangal extract as botanical fungicide against $P$. euvitis, compared with mancozeb. The methods were galangal extract preparation in evaporated methanol, in vitro toxicity test of galangal extract for $\mathrm{LC}_{50}$ determination, and in planta test using grape seedlings in polybags. $\mathrm{LC}_{50}$ was determined by using SAS JMP Statistical Discovery Program. In planta test was carried out by spraying urediniospore suspension with density of $1 \times 10^{6}$ spores $\mathrm{mL}^{-1}$, followed by galangal extract or mancozeb spraying at $\mathrm{LC}_{90}$ concentration three days after inoculation. The result showed that galangal extract inhibited spore germination of $P$. euvitis. $\mathrm{LC}_{50}$ of the galangal extract was $18.33 \mathrm{ppm}$; $\mathrm{LC}_{90}$ was $53.72 \mathrm{ppm}$; while mancozeb $\mathrm{LC}_{50}$ was $65.52 \mathrm{ppm}$ and $\mathrm{LC}_{90}$ was $190.71 \mathrm{ppm}$. In
\end{abstract}

*Alamat penulis korespondensi: Fakultas Pertanian Universitas Gadjah Mada, Jalan Flora No. 1 Bulaksumur, Yogyakarta, Indonesia, 55281.

Telepon dan Fax.: +62-274-523926, Surel: aniwidiastuti@ugm.ac.id 
planta experiment showed that galangal extract of $53.72 \mathrm{ppm}\left(\mathrm{LC}_{90}\right)$ reduced the disease intensity of leaf rust by $16 \%$ on the $18^{\text {th }}$ day, while mancozeb of $190.71 \mathrm{ppm}\left(\mathrm{LC}_{90}\right)$ reduced the disease intensity by $26.4 \%$ compared to positive control or untreated-inoculated plants. This study showed that galangal extract is potential to be developed as botanical fungicide to control grape leaf rust disease.

Key words: disease control, $\mathrm{LC}_{50}$, mancozeb

\section{PENDAHULUAN}

Penyakit karat daun (Phakopsora euvitis) merupakan salah satu penyakit penting pada tanaman anggur karena pustul karat yang dihasilkan cendawan dapat mengganggu proses fotosintesis. Pada infeksi yang berat seluruh permukaan bawah daun tertutup pustul karat berwarna kuning dan daun akan segera rontok. Tanaman sakit hanya mempunyai sedikit daun, pertumbuhan tunas sedikit sehingga keperluan nutrisi dari hasil fotosintesis menjadi tidak terpenuhi dan pada akhirnya menurunkan kuantitas dan kualitas buah (Stephens 2005). Inokulum sering ditemukan pada permukaan daun anggur yang telah rontok dan jatuh ke tanah sehingga mudah terpencar oleh angin. Cendawan berkembang baik pada lingkungan dengan kelembapan tinggi (Jose 2005).

Cendawan $P$. euvitis memiliki kisaran inang pada sekitar 15 spesies Vitis spp. dan 2 spesies Meliosma spp. yaitu Meliosma cuneifolia (China) atau M. myriantha (Jepang), sebagai inang alternatif untuk pembentukan spermatium dan spermagonium (CABI 2015; Ono 2000). Jenis anggur yang dikenal masyarakat Indonesia hanya ada beberapa, menurut Departemen Pertanian RI anggur yang cocok dengan kondisi alam Indonesia seperti jenis anggur Probolinggo Biru, Gross Colman, dan Anggur Bali. Anggur yang banyak dan terkenal di Indonesia sebenarnya hanya ada 2 spesies, yaitu $V$. vinifera dan $V$. labrusca (Faryeti 2008); keduanya rentan terhadap karat daun anggur (CABI 2015).

Praktik pengendalian penyakit tanaman menggunakan pestisida nabati untuk mengurangi penggunaan pestisida kimiawi meningkat seiring dengan kesadaran masyarakat akan efek samping pestisida kimiawi yang diaplikasikan dalam waktu lama (Damalas dan Koutroubas 2018). Pestisida nabati sebagai salah satu jenis pestisida alami yang memanfaatkan bahan baku dari tumbuhan telah banyak digunakan, karena kandungan bahan aktif alaminya lebih mudah terdegradasi dan lebih aman bagi lingkungan (Djunaedy 2009). Lengkuas (Alpinia galanga) mudah diperoleh di Indonesia serta berperan sebagai anticendawan dan antibakteri (Qiptiyah et al. 2015). Avasthi et al. (2015) menunjukkan bahwa fraksi metanol rimpang lengkuas memiliki aktivitas penghambatan pertumbuhan mikrob secara in vitro pada beberapa spesies bakteri dan cendawan. Sundari dan Winarno (2000) menunjukkan bahwa infus ekstrak etanol rimpang lengkuas yang berisi minyak atsiri menghambat pertumbuhan beberapa spesies cendawan patogen, yaitu Tricophyton, Mycrosporum gypseum, dan Epidermo floccasum. Handajani dan Purwoko (2008) menunjukkan ekstrak rimpang lengkuas memiliki aktivitas anticendawan terhadap Fusarium moniliforme dan Aspergillus spp. Oleh karena itu, dalam penelitian ini dilakukan pengujian potensi ekstrak lengkuas sebagai pestisida nabati terhadap P. euvitis secara in vitro dan in planta. Fungisida mankozeb digunakan sebagai pembanding perlakuan ekstrak lengkuas.

\section{BAHAN DAN METODE}

Bibit anggur yang digunakan ialah varietas Red Prince/Prabu Bestari hasil setek, yang telah memiliki minimal 5 daun muda, berdiameter batang 50-100 mm dengan jumlah ruas batang 3-5 ruas. Bibit anggur ditanam pada medium tanaman campuran tanah dan pupuk kompos (3:2) dalam pot plastik ukuran $1 \mathrm{~kg}$ dan disiram setiap sore hari.

Isolat $P$. euvitis yang bersifat parasit obligat dipelihara dengan menyemprotkan suspensi uediniospora cendawan pada daun tanaman 
sehat. Selanjutnya tanaman diinkubasi di rumah plastik hingga gejala muncul dan cendawan bersporulasi. Morfologi cendawan diidentifikasi dengan mengamati sporanya secara mikroskopis dan dibandingkan dengan pustaka (Jose 2005). Spora P. euvitis ini disiapkan untuk uji lanjut.

\section{Pembuatan Pestisida Nabati Ekstrak Lengkuas}

Sebanyak $1 \mathrm{~kg}$ rimpang lengkuas dicuci bersih dan diiris tipis dengan ketebalan $\pm 4 \mathrm{~mm}$ untuk memudahkan ekstraksi. Irisan rimpang dikeringanginkan selama 3 hari dalam oven bersuhu $50{ }^{\circ} \mathrm{C}$ sampai mencapai kadar air $10 \%-12 \%$. Proses ekstraksi dilakukan dengan metode ekstraksi Soxhlet, yaitu sebanyak $150 \mathrm{~mL}$ metanol dan $5 \mathrm{~g}$ lengkuas kering yang dibungkus kertas saring dimasukkan dalam labu didih, lalu diletakan dalam ekstraktor. Pemanas dilakukan pada suhu $60{ }^{\circ} \mathrm{C}$ dan sebagai pendingin, air dialirkan pada kondensor. Proses ekstraksi dilakukan selama 6 jam. Hasil ekstraksi diuapkan secara vakum menggunakan rotary vacuum evaporator pada suhu $60{ }^{\circ} \mathrm{C}$ yang bertujuan untuk memisahkan minyak lengkuas dari metanol. Minyak hasil evaporasi vakum diencerkan dengan akuades steril sesuai konsentrasi yang digunakan.

\section{Pengujian Daya Racun Pestisida untuk Penentuan $\mathrm{LC}_{50}$}

Sebanyak $5 \mathrm{~mL}$ medium agar air (AA) dimasukkan ke dalam cawan petri, ditunggu hingga dingin kemudian $100 \mu \mathrm{L}$ larutan uji diteteskan di atas pada medium AA. Pengujian awal ekstrak lengkuas dilakukan dengan metode teknik makanan beracun pada berbagai konsentrasi untuk mendapatkan konsentrasi ekstrak yang mampu menekan $90 \%$ perkecambahan spora $(62.5 \mathrm{ppm})$. Konsentrasi yang telah didapat kemudian diencerkan $1 / 2$ dan $1 / 4$ konsentrasi. Hasil ini digunakan sebagai dasar perhitungan uji untuk mendapatkan $\mathrm{LC}_{50}$ ekstrak lengkuas berdasarkan analisis statistik.

Konsentrasi larutan ekstrak lengkuas yang digunakan ialah: 0 ppm (kontrol), $15.625 \mathrm{ppm}$, $31.25 \mathrm{ppm}$, dan $62.5 \mathrm{ppm}$; sedangkan fungisida mankozeb disiapkan dengan konsentrasi: 0 ppm (kontrol), 50 ppm, 100 ppm, dan 200 ppm. Setiap konsentrasi diulang 4 kali, kemudian ditunggu sekitar 5 jam hingga pestisida meresap. Sebanyak $100 \mu \mathrm{L}$ suspensi spora $P$. euvitis $\left(1 \times 10^{6}\right.$ spora $\left.\mathrm{mL}^{-1}\right)$ diteteskan di atas medium AA dan diinkubasi dalam suhu kamar dengan kondisi gelap selama 12 jam agar spora berkecambah. Persentase spora yang tidak berkecambah terhadap jumlah total spora dihitung. Besarnya persentase penghambatan perkecambahan spora dihitung dari pengurangan persentase spora tidak berkecambah pada konsentrasi tertinggi dengan konsentrasi uji.

\section{Analisis Data $\mathrm{LC}_{50}$ Daya Racun Pestisida}

Data persentase penghambatan perkecambahan spora $P$. euvitis yang diperoleh dari pengujian di atas, dianalisis menggunakan program SAS JMP Statistical Discovery untuk mendapatkan konsentrasi bahan yang mampu membunuh $50 \%$ populasi patogen $\left(\mathrm{LC}_{50}\right)$ dan yang mampu membunuh $90 \%$ populasi patogen $\left(\mathrm{LC}_{90}\right)$ dari setiap pestisida yang digunakan. $\mathrm{LC}_{50}$ dan $\mathrm{LC}_{90}$ masing-masing bahan ini kemudian digunakan sebagai dasar pengujian berikutnya.

\section{Pengujian Pestisida in Planta pada Tanaman Anggur}

Tanaman anggur yang digunakan ialah tanaman yang memiliki minimal 5 helai daun, dengan ulangan 10 tanaman. Suspensi urediniospora $P$. euvitis $\left(1 \times 10^{6}\right.$ spora $\left.\mathrm{mL}^{-1}\right)$ disemprotkan sampai run off pada 5 daun per tanaman (permukaan daun bagian bawah) (Nogueira Júnior et al. 2017). Aplikasi dilakukan pada sore hari. Bagian permukaan tanah ditutupi dengan kapas basah untuk menjaga kelembapan. Selanjutnya, tanaman anggur disungkup dengan plastik transparan yang telah dilubangi, agar kelembapan mikro terjaga selama semalaman. Tiga hari setelah daun anggur diinokulasi $P$. euvitis, daun disemprot dengan air steril (0 ppmkontrol); $\mathrm{LC}_{90}$ ekstrak lengkuas dan $\mathrm{LC}_{90}$ mankozeb, yang didapatkan dari hasil analisis sebelumnya. 


\section{Pengamatan dan Analisis Data}

Penelitian disusun dengan rancangan acak lengkap yang terdiri atas 3 perlakuan dengan 10 ulangan. Pengamatan keparahan penyakit dilakukan setiap 3 hari, selama 21 hari. Keparahan penyakit (KP) dihitung dengan menggunakan rumus:

$$
\mathrm{KP}=\frac{\sum_{\mathrm{i}=0}^{i}\left(\mathrm{n}_{i} \times \mathrm{v}_{i}\right)}{\mathrm{N} \times \mathrm{V}^{*}} 100 \% \text {, dengan }
$$

$\mathrm{n}_{\mathrm{i},}$ jumlah tanaman dengan skor ke-i; $\mathrm{v}_{\mathrm{i}}$, nilai skor penyakit dari $\mathrm{I}=0,1,2$ sampai i t-skor tertinggi; $\mathrm{N}$, jumlah tanaman yang diamati; dan V, skor tertinggi. Skor keparahan penukit mengacu pada Tarr (1972) (Gambar 1). kemudian data dianalisis dengan Uji DMRT (Duncan Multiple Range Test) pada $\alpha$ 5\%.

\section{HASIL}

\section{Pengamatan mikroskopi $P$. euvitis}

Morfologi cendawan penyebab karat daun kemiripan dengan $P$. euvitis seperti yang dituliskan Jose (2005), meskipun ukuran sporanya sedikit berbeda. Urediniospoa cendawan berbentuk lonjong dan berukuran 11.6-15.4 $\mu \mathrm{m} \times 8.5-2.1 \mu \mathrm{m}$ (Gambar 2).

\section{Daya Racun Pestisida Ekstrak Lengkuas Dibandingkan dengan Fungisida Mankozeb}

Hasil pengamatan 12 jam setelah perlakuan menunjukkan bahwa ekstrak lengkuas memiliki kemampuan menghambat perkecambahan spora $P$. euvitis. Ekstrak lengkuas dengan konsentrasi 15.625 ppm memiliki penghambatan 59.81\%, pada konsentrasi 31.25 ppm penghambatannya sebesar $72.83 \%$, dan penghambatan tertinggi ekstrak lengkuas pada konsentrasi 62.5 ppm, yaitu 95.73\% (Gambar 3). Penghambatan pada kontrol ialah sebesar $9.28 \%$ dan masih diterima karena tidak lebih dari 10\%. Data tersebut diinterpolasi ke dalam grafik perkecambahan

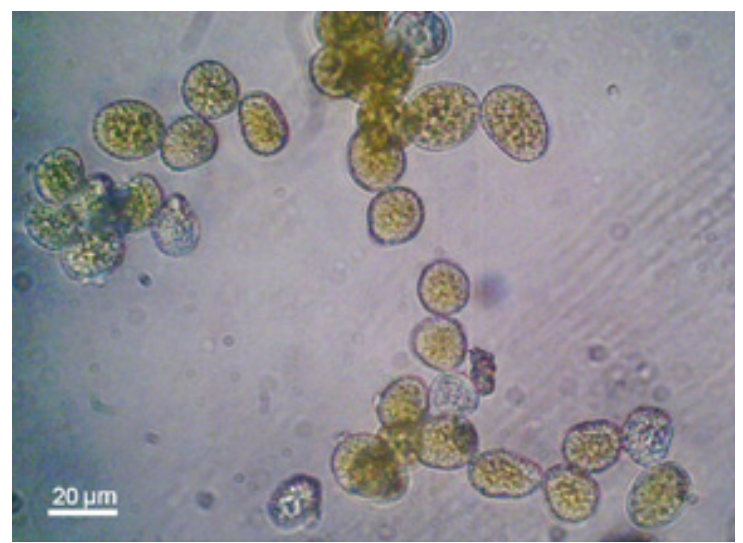

Gambar 2 Urediniospora Phakopsora euvitis

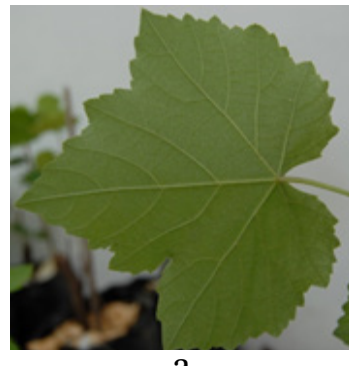

a

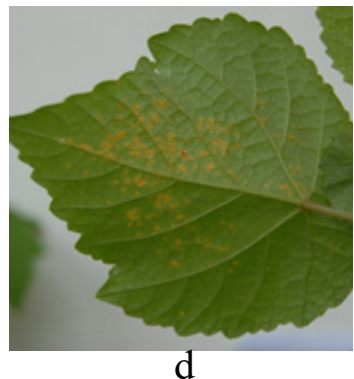

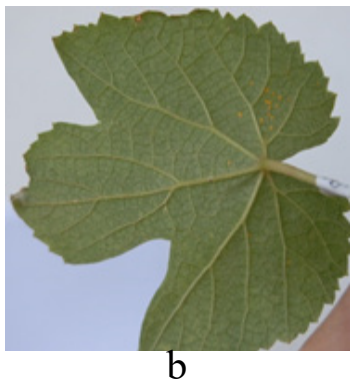

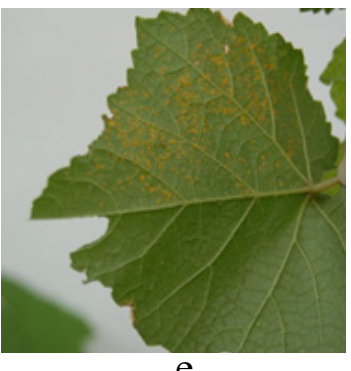

e
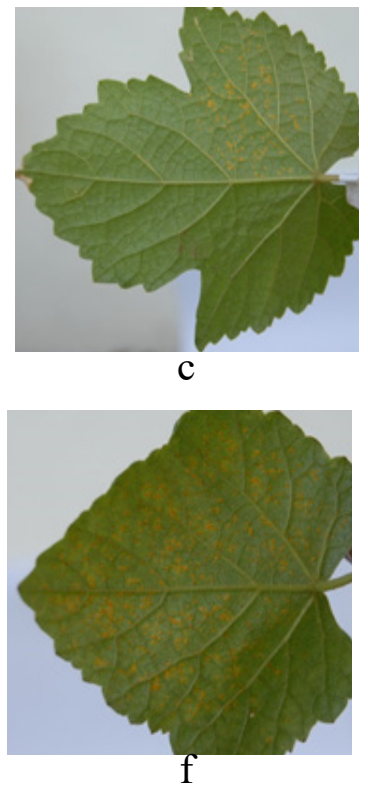

Gambar 1 Skala infeksi penyakit karat daun anggur. a, Skala 0 (Tidak ada infeksi); b, Skala 1 (infeksi sangat ringan; $<5 \%$ daun terinfeksi); c, Skala 2 (infeksi ringan; 5-10\% daun terinfeksi); d, Skala 3 (infeksi sedang; 10-25\% daun terinfeksi); e, Skala 4 (infeksi berat; 25-50\% daun terinfeksi); f, Skala 5 (infeksi sangat berat; $>50 \%$ daun terinfeksi). 
spora P. euvitis dengan aplikasi ekstrak lengkuas (Gambar 3), dan didapatkan persamaan regresi yakni $\mathrm{y}=1.2617 \mathrm{x}+24.912$ dengan $\mathrm{R}^{2}$ sebesar 0.8476. Pengujian ekstrak lengkuas pada konsentrasi 62.5 ppm menyebabkan perkecambahan spora terendah dibandingkan dengan konsentrasi di bawahnya (Gambar 4).

Perlakuan mankozeb 50 ppm menghambat perkecambahan P. euvitis sebesar $66.43 \%$ dan pada konsentrasi 100 ppm penghambatannya mencapai $70.44 \%$. Tingkat penghambatan paling tinggi ialah penggunaan mankozeb
200 ppm, yaitu sebesar 84.88\%. Penghambatan pada kontrol (0 ppm) hanya $6.42 \%$. Data tersebut diinterpolasi ke dalam grafik perkecambahan spora $P$. euvitis dengan aplikasi mankozeb (Gambar 5), dan didapatkan persamaan regresi yakni $y=0.372 x+27.536$ dengan $\mathrm{R}^{2}$ sebesar 0.69 . Pada pengujian ini, perkecambahan spora terendah terlihat pada konsentrasi mancozeb 200 ppm (Gambar 6).

Dengan menggunakan program $S A S J M P$ Statistical Discovery didapat $\mathrm{LC}_{50}$ ekstrak lengkuas sebesar 18.33 ppm dan $\mathrm{LC}_{90}$ sebesar

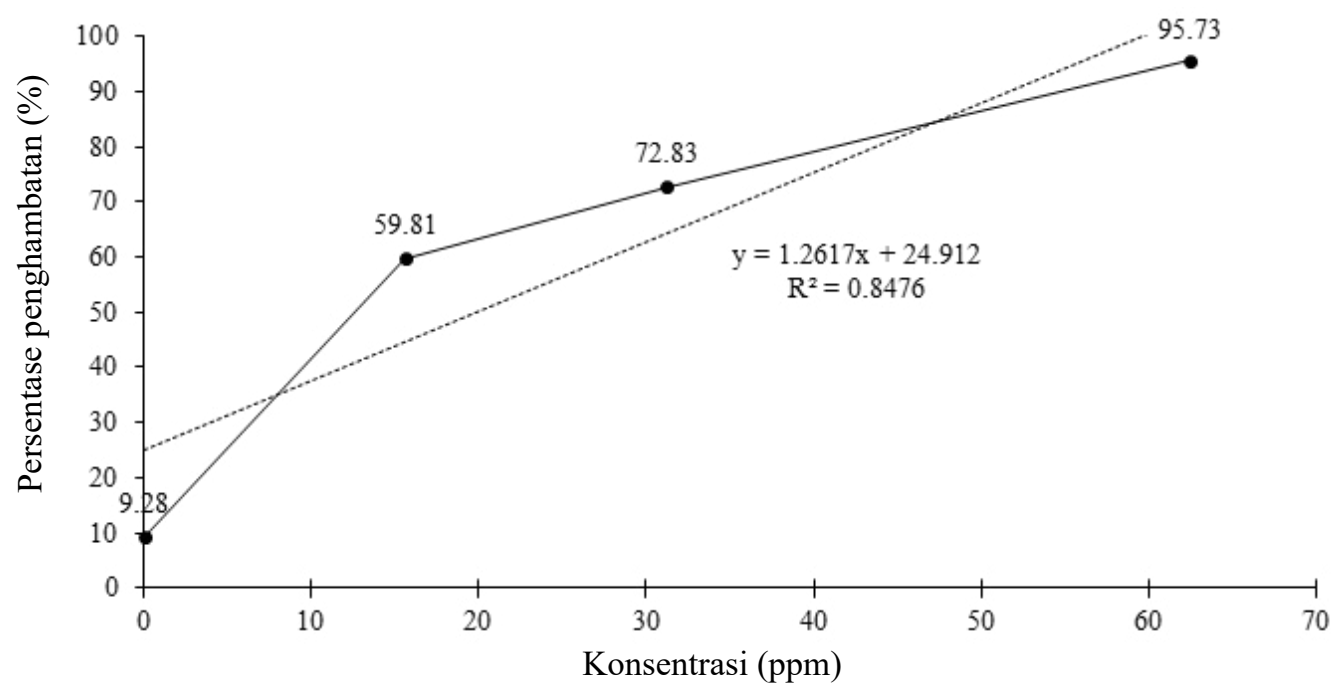

Gambar 3 Penghambatan perkecambahan urediniospora Phakopsora euvitis pada medium mengandung ekstrak lengkuas

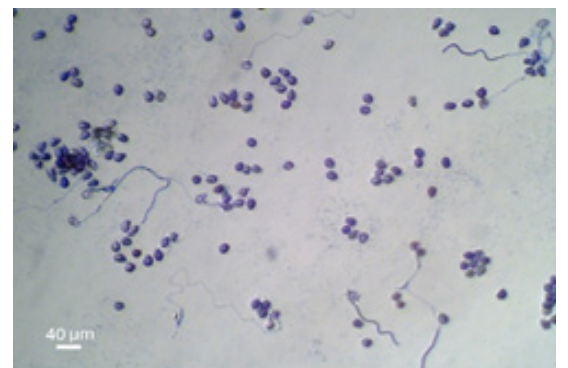

$\mathrm{a}$

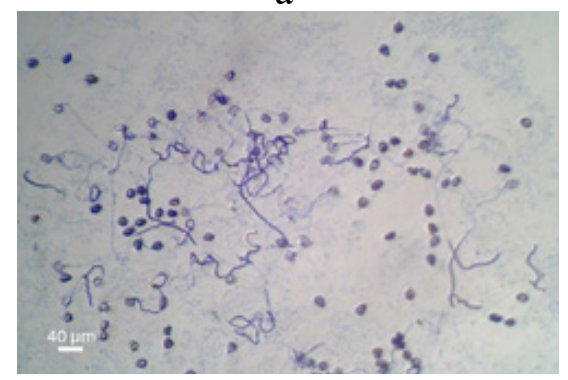

$\mathrm{C}$

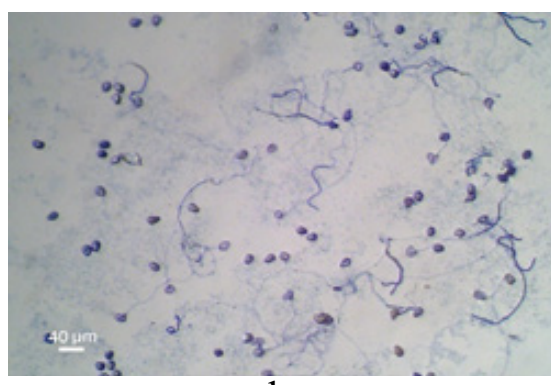

b

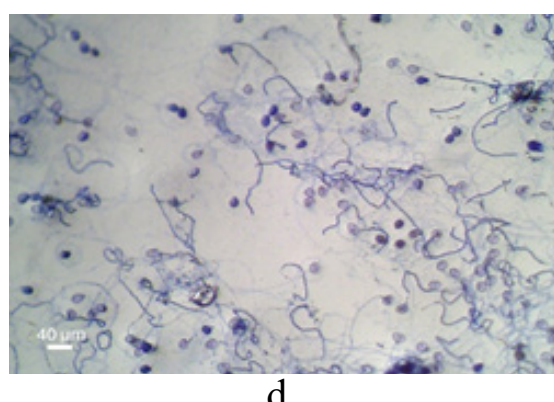

d

Gambar 4 Perkecambahan uredinispora Phakopsora euvitis pada berbagai konsentrasi ekstrak lengkuas. a, 62.5 ppm; b, 31.25 ppm; c, 15.63 ppm; dan d, 0 ppm (kontrol). 
53.72 ppm; sementara $\mathrm{LC}_{50}$ mankozeb sebesar $65.52 \mathrm{ppm}$ dan $\mathrm{LC}_{90}$ sebesar $190.71 \mathrm{ppm}$.

\section{Pengujian Pestisida in Planta pada} Tanaman Anggur

Pada hari ke-18, keparahan penyakit karat daun anggur pada perlakuan kontrol ialah $27.6 \%$. Penyemprotan ekstrak lengkuas $\mathrm{LC}_{90}$ menghasilkan KP sebesar $11.6 \%$, sedangkan perlakuan mankozeb $\mathrm{LC}_{90} \mathrm{KP}$-nya sebesar 1.2\% (Gambar 6). Jika dibandingkan dengan kontrol, perlakuan mankozeb memberikan penurunan keparahan penyakit terbesar yaitu $26.4 \%$, sedangkan ekstrak lengkuas hanya $16 \%$ (Gambar 7).

\section{PEMBAHASAN}

Ekstrak lengkuas memiliki kandungan senyawa minyak atsiri di antaranya, yaitu d-limonen; eukaliptol; 3-sikloheksen-1-ol, 4-metil-1-(1-metietil); Fenol, 4-(2-profenil)asetat; 2,6-oktadien-1-ol, 3,7-dimetilasetat; 1,6,10-dodekatrien, 7,11-dimetil-3-metilen;

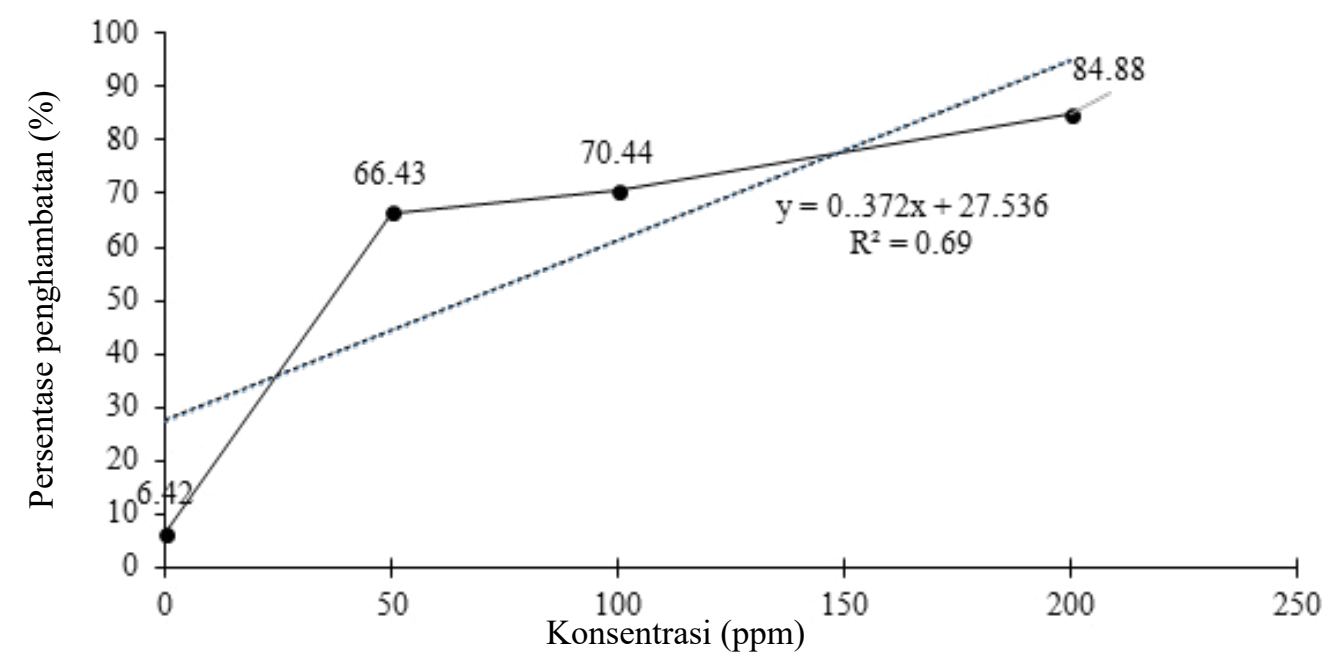

Gambar 5 Penghambatan perkecambahan urediniospora Phakopsora euvitis pada medium yang mengandung mankozeb.

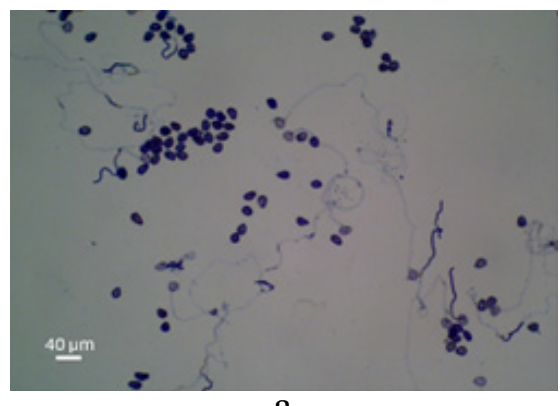

a

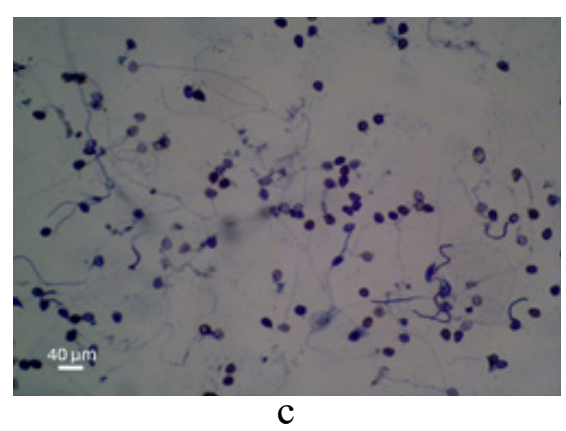

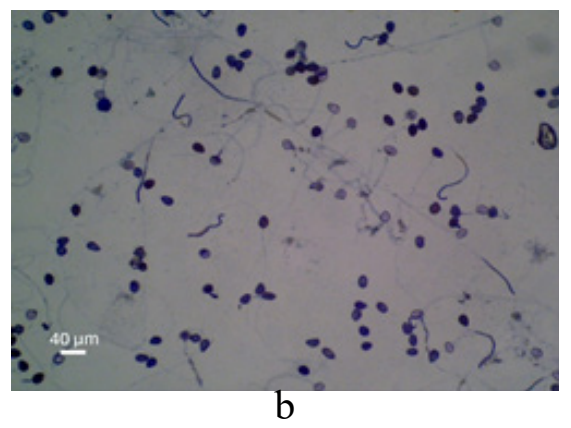

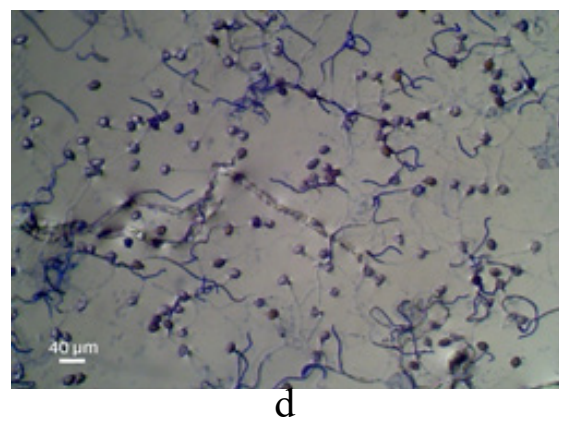

Gambar 6 Perkecambahan urediniospora Phakopsora euvitis pada medium dengan berbagai tingkat konsentrasi mankozeb. a: 200 ppm; b: 100 ppm; c: 50 ppm; dan d: 0 ppm (kontrol) 


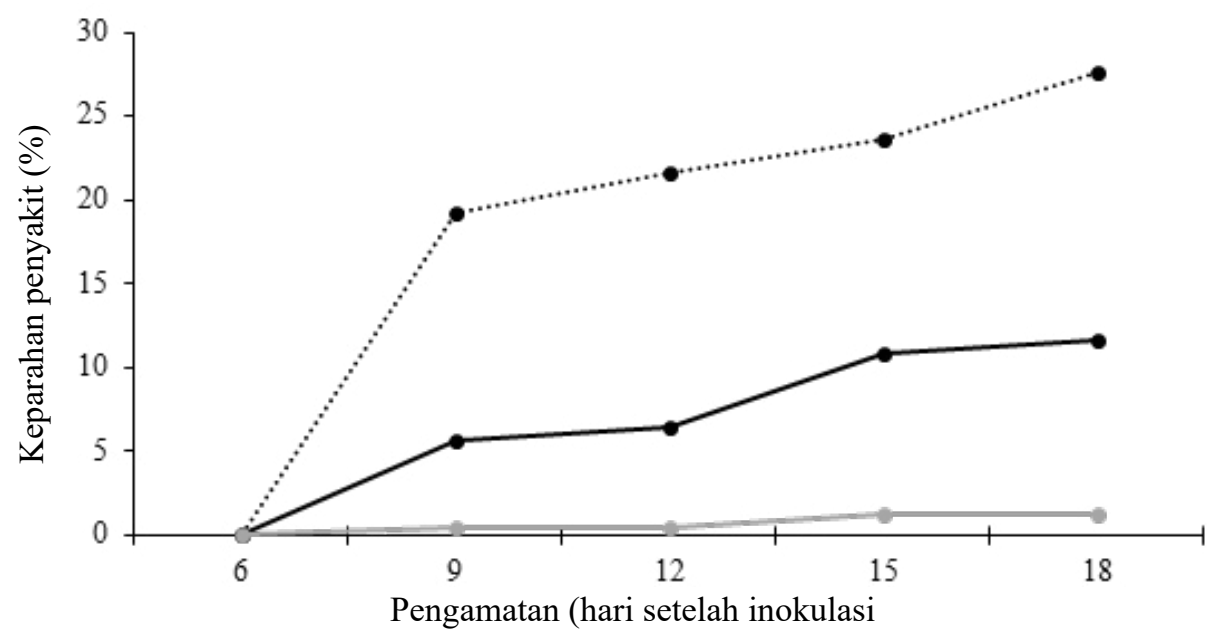

Gambar 7 Perkembangan keparahan penyakit karat pada anggur setelah aplikasi ekstrak lengkuas dan mankozeb. $\cdots \bullet \cdots$, Kontrol; $\rightarrow$, Ekstrak lengkuas; $\longrightarrow$, Mankozeb.

Pentadesen; sikloheksen, 1-metil-4-(5-metil1-metilen-4-heksenil), juga senyawa flavonoid dan terpenoid (Parwata dan Dewi 2008; Suaib et al. 2016). Senyawa fenol memiliki sifat korosif yang mampu mendenaturasi protein pada dinding sel mikroba dan menonaktifkan enzim. Senyawa fenol telah banyak dilaporkan memiliki kemampuan antifungal. Mekanisme antifungal terjadi antara lain karena senyawa tersebut menyebabkan kerusakan secara permanen pada dinding sel cendawan, koagulasi sel dan penghambatan metabolism enzim intraseluler. Secara khusus, senyawa fenolik bersifat hidrofobik dan diikat oleh lapisan lipid bilayer dari membran sel cendawan yang menyebabkan gangguan struktural dan hilangnya integritas sel. Akibatnya sel cendawan tidak dapat berkembang (Kalogianni et al. 2020). Proses ini yang diduga terjadi pada ekstrak langkuas dalam menghambat perkecambahan $P$. euvitis. Konsentrasi pestisida berkorelasi positif terhadap spora cendawan yang tidak berkecambah, yang berarti semakin tinggi konsentrasi ekstrak lengkuas semakin banyak spora yang tidak berkecambah. Konsentrasi ekstrak lengkuas sebesar 62.5 ppm memiliki kemampuan penekanan perkecambahan spora tertinggi dalam uji ini.

Mankozeb adalah salah satu fungisida grup ditiokarbamat (Mn-Zn-ethylene bisdiothio carbamate-EBDC) (Sumardiyono 2013), yaitu jenis fungisida kontak berspektrum luas sehingga digunakan sebagai perlakuan pembanding. Uji makanan beracun dengan mancozeb menunjukkan hasil efektif menghambat perkecambahan spora $P$. euvitis. Semakin tinggi konsentrasimancozeb, semakin tinggi pula kemampuan penghambatannya. Nilai $\mathrm{R}^{2}$ pada persamaan regresinya menunjukkan bahwa konsentrasi pestisida mancozeb berkorelasi positif terhadap spora cendawan yang tidak berkecambah, semakin tinggi konsentrasi mankozeb semakin banyak spora yang tidak berkecambah.

Hasil $\mathrm{LC}_{50}$ dan $\mathrm{LC}_{90}$ ekstrak lengkuas lebih rendah dibanding mankozeb, artinya ekstrak lengkuas memiliki kemampuan daya racun lebih tinggi daripada mankozeb. Hal ini menunjukkan potensi ekstrak lengkuas sebagai fungisida nabati terhadap P. euvitis. Aktivitas penekanan perkecambahan spora dari ekstrak lengkuas disebabkan oleh kandungan pada ekstrak lengkuas, yaitu minyak atsiri 1\%, metilsinamat, sineol, kamfer, d-pinen, eugenol, camfor, galangal, dan cadinen. Senyawa eugenol diketahui mampu menghancurkan membran lipid bilayer sehingga sel kehilangan struktur dan fungsinya, serta mengakibatkan lisis (Singh dan Rai 2000).

Pada uji in planta nampak bahwa ekstrak lengkuas memiliki kemampuan untuk menekan perkembangan penyakit karat daun anggur meskipun keparahan penyakitnya masih di atas perlakuan mankozeb. Kandungan utama ekstrak lengkuas ialah minyak atsiri antara 
lain, yaitu monoterpen dan seskuiterpen yang bersifat volatil (Silalahi 2017) sehingga diduga material yang efektif menekan perkecambahan cendawan pada ekstrak lengkuas ini mengalami penguapan pada saat aplikasi in planta. Hal ini menyebabkan efektivitas pengendalian menjadi lebih rendah dibandingkan dengan mankozeb meskipun konsentrasinya setara $\mathrm{LC}_{90}$ pada masing-masing bahan. Periode inkubasi penyakit karat daun anggur ialah 9 hari sehingga disarankan untuk melakukan pengulangan aplikasi pada interval 7 hari atau kurang dari periode inkubasi.

Hasil penelitian ini menunjukkan bahwa ekstrak lengkuas memiliki potensi sebagai fungisida nabati terhadap penyakit karat daun anggur ( $P$. euvitis). Material anticendawan yang terkandung di dalam ekstrak lengkuas bersifat volatil maka penelitian tentang formulasi untuk menekan volatilitas senyawa aktif penting untuk dikembangkan.

\section{UCAPAN TERIMA KASIH}

Penelitian ini adalah bagian dari penelitian skripsi berjudul Uji Pestisida Nabati dari Lengkuas terhadap Phakopsora euvitis Penyebab Penyakit Karat Daun Anggur (2015) Reza Fredo Simarmata dibawah bimbingan Ani Widiastuti dan Christanti Sumardiyono. Penulis menyatakan tidak ada conflict of interest dalam penulisan artikel ini.

\section{DAFTAR PUSTAKA}

Avasthi SA, Jain S, Bhatnagar M, Ghosal S. 2015. In vitro antibacterial, antifungal, antioxidant and antihemolytic activities of Alpinia galanga. Int J Phytomedicine. 7(1):78-89.

[CABI]. 2015. Phakopsora euvitis (grape rust fungus). [http://www.cabi.org/ isc/ datasheet/40016]. Diakses pada 15 September 2015.

Djunaedy A. 2009. Biopestisida sebagai pengendali organisme pengganggu tanaman (OPT) yang ramah lingkungan. J Embryo. 6(1):88-95.
Damalas CA, Koutroubas SD. 2018. Current status and recent development in biopesticide use. Agriculture. 8(13). DOI: https://doi.org/10.3390/ agriculture8010013.

Faryeti S. 2008. Tanaman anggur di Indonesia. Laporan Forum Kerjasama Agribisnis, Depok.

Handajani NS, Purwoko T. 2008. The activity of galanga (Alpinia galanga) rhizome extract against the growth of filamentous fungi Aspergillus spp. that produce aflatoxin and Fusarium moniliforme. Biodiversitas. 9(3):161-164. DOI: https:// doi.org/10.13057/biodiv/d090301.

Kalogianni AI, Lazou T, Bossis I, Gelasakis AI. 2020. Natural phenolic compounds for the control of oxidation, bacterial spoilage, and foodborne pathogens in meat. Foods. 9:794. DOI: https://doi.org/10.3390/ foods 9060794 .

Jose R. 2005. Urediniospores of Phakopsora euvitis on Vitis vinifera. PaDIL Species Factsheet. [http://www.padil.gov.au:80/ pests-anddiseases/Pest/Main/136602]. Diakses pada 27 Agustus 2015.

Nogueira Júnior AF, Ribeiro RV, Appezzatoda-Glória B, Soares MK, Rasera JB, Amorim L. 2017. Phakopsora euvitis causes unusual damage to leaves and modifies carbohydrate metabolism in grapevine. Front Plant Sci. 8:1675. DOI: https://doi.org/10.3389/fpls.2017.01675.

Ono Y. 2000. Taxonomy of the Phakopsora ampelopsidis species complex on Vitaceous hosts in Asia including a new species, P. euvitis. J Mycologia. 92(1): 154-173. DOI: https://doi.org/10.2307/3761460.

Parwata IM, Dewi PFS. 2008. Isolasi dan uji aktivitas antibakteri minyak atsiri dari rimpang lengkuas (Alpinia galanga $\mathrm{L}$.). J Kimia. 2(2):100-104.

Qiptiyah F, Wahyuni D, Aisyah IN. 2015. Potensi ekstrak rimpang lengkuas merah (Alpinia purpurata K. Schum) dalam pengendalian jamur Hemileia vastartix $b$. et br. pada kopi arabika (coffea arabica). Pancaran Pendidikan. 4(2):103-114.

Silalahi M. 2017. Essential oil pada Alpinia 
galangal (L) Willd dan pemanfaatannya. J. Pro-Life. 4(1): 287-296.

Singh R, Rai B. 2000. Antifungal potential of some higher plants against Fusarium udum causing wilt disease of Cajanus cajan. J Microbios. 102:165-173.

Stephens PR. 2005. Phakopsora euvitis. PaDIL Species Factsheet. [http://www. padil. gov.au:80/pests-and-diseases/Pest/ Main/136602]. Diakses pada 27 Agustus 2015.

Suaib IS. Lakani I. Panggeso J. 2016. Efektivitas ekstrak rimpang lengkuas dalam menghambat aktivitas cendawan
Oncobasidium theobromae secara in vitro. J Agrotekbis. 4(5):506-511.

Sumardiyono C. 2013. Pengantar Toksikologi Fungisida. Gama Press.

Sundari D, Winarno MW. 2001. Informasi tumbuhan obat sebagai anti jamur. Cermin Dunia Kedokteran. 130:28-30.

Tarr SAJ. 1972. The Principles of Plant Pathology. London (UK): The Macmillan Press. DOI: https://doi.org/10.1007/978-1349-00355-6. 